\title{
THE RELATIONSHIP BETWEEN NURSING CARE AND PATIENT SATISFACTION USING HALL THEORY AT LEWOLEBA HOSPITAL, EAST NUSA TENGGARA
}

\author{
Emanuel Petrus Padak Botoor
}

\author{
Masters Program in Public Health, Faculty in Public Health, \\ Universitas Undana Kupang
}

\begin{abstract}
Background: Patient satisfaction is an important and commonly used indicator for measuring the quality in health care. In the Lewoleba Hospital, Kupang, East Nusa Tenggara, there are still many nurses who are rude and careless to patients. It often leaves patients confused and slowly responded. Lydia Eloise Hall (Hall Theory) emphasizes the process of good nursing care by applying the "Care, Core and Cure $\left(\mathrm{C}_{3}\right)$ Aspects" in the patient's nursing care process. This study aimed to investigate the relationship between nursing care and patient satisfaction using Hall Theory at Lewoleba Hospital, Kupang, East Nusa Tenggara.

Subjects and Methods: A cross-sectional study was conducted at Lewoleba Hospital, Kupang, East Nusa Tenggara. A total sample of 66 patients was selected for this study by total sampling. The dependent variable was patients' satisfaction. The independent variables were Care (biology, health promotion, interpersonal relationship), Core (patient comfort and confidence, empathy attitude), and Cure (the role of advocate, treatment and motivation). The data were collected by questionnaire and analyzed descriptively.

Results: Biology and health promotion (Care), patient comfort and confidence, and empathy attitude (Core), and the role of advocate (Cure) were associated with patients' satisfaction, and they were statistically significant $(\mathrm{p}<0.050)$. The associations of interpersonal relationship (Care), treatment, and motivation (Care), were not statistically significant with patients' satisfaction $(\mathrm{p}=0.117)$.

Conclusion: Care, Core, and Cure aspects as in Hall Theory are associated with patient satisfaction.
\end{abstract}

Keywords: patient satisfaction, nursing care, care, core, cure, Hall Theory

\section{Correspondence:}

Emanuel Petrus Padak Botoor. Masters Program in Public Health, Faculty in Public Health, Universitas Nusa Cendana, Kupang, East Nusa Tenggara. Email: Emanuelbotoor86@gmail.com. Mobile: 08122996216. 